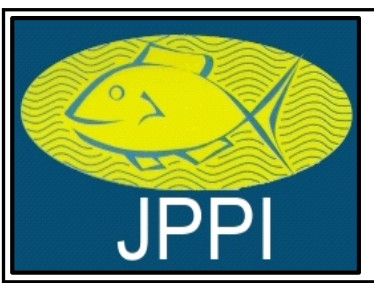

\author{
Tersedia online di: http://ejournal-balitbang.kkp.go.id/index.php/jppi \\ e-mail:jppi.puslitbangkan@gmail.com \\ JURNAL PENELITIANPERIKANANINDONESIA \\ Volume 24 Nomor 4 Desember 2018 \\ p-ISSN: 0853-5884 \\ e-ISSN: 2502-6542 \\ Nomor Akreditasi RISTEKDIKTI: 21/E/KPT/2018
}

\title{
PERCOBAAN PENANDAAN LOBSTER PASIR (Panulirus homarus Linnaeus, 1758) DI TELUK PRIGI
}

\section{TAGGING EXPERIMENT OF SCALLOPED SPINY LOBSTERS (Panulirus homarus Linnaeus, 1758) IN GULF OF PRIGI}

\author{
Danu Wijaya ${ }^{* 1}$ dan Amula Nurfiarini ${ }^{1}$ \\ ${ }^{1}$ Balai Riset Pemulihan Sumber Daya Ikan, Jl. Cilalawi No.1, Jatiluhur, Purwakarta, Jawa Barat, 41152, Indonesia \\ Teregistrasi I tanggal: 30 Nopember 2018; Diterima setelah perbaikan tanggal: 19 Februari 2019; \\ Disetujui terbit tanggal: 25 Februari 2019
}

\begin{abstract}
ABSTRAK
Percobaan penebaran lobster pasir (Panulirus homarus) di Perairan Teluk Prigi, Kabupaten Trenggalek dilakukan pada 2015. Percobaan dilakukan dengan cara memberi tanda (tag) pada seluruh sampel lobster pasir yang ditebar, dikenal sebagai metode Capture-mark-recapture (CMR) dan sudah banyak digunakan untuk mempelajari populasi biota di alam. Penelitian bertujuan untuk mengetahui tingkat tertangkap kembali, laju pertumbuhan, dan pergerakan lobster pasir bertanda di Teluk Prigi. Penebaran lobster pasir bertanda dilakukan pada tiga lokasi yaitu Damas, Karanggongso dan Karangasem dengan jumlah 2.784 ekor dan diberi tanda jenis T-bar berwarna merah yang memiliki kode. Pengamatan lobster pasir bertanda yang tertangkap kembali dilakukan sepanjang tahun 2016 di Teluk Prigi (Februari-Desember). Tingkat tertangkap kembali lobster bertanda dihitung menggunakan proporsi antara lobster bertanda yang tertangkap dengan lobster bertanda yang ditebar. Laju pertumbuhan lobster bertanda yang tertangkap kembali dihitung berdasarkan pertumbuhan per satuan waktu yang sama dengan perubahan panjang dibagi dengan perubahan umur. Pergerakan lobster bertanda diukur melalui jarak dari lokasi tebar sampai dengan lokasi lobster bertanda yang tertangkap kembali. Tingkat tertangkap kembali lobster pasir ( $P$. homarus) bertanda di Teluk Prigi sebanyak 4,7\%. Laju pertumbuhan lobster pasir yang tertangkap kembali rata-rata 0,09 $\pm 0,05$ $\mathrm{mm} /$ hari. Pergerakan lobster pasir bertanda yang tertangkap kembali di Teluk Prigi berkisar antara 0,1-11,36 km. Pergerakan lobster pasir bertanda memiliki kecenderungan acak dan tetap pada wilayah pantai.
\end{abstract}

Kata Kunci: Lobster pasir; tingkat tertangkap kembali; laju pertumbuhan; pergerakan; Teluk Prigi

\begin{abstract}
In 2015, restocking experiment of Scalloped spiny lobster (Panulirus homarus) was conducted in Gulf of Prigi, Trenggalek Regency and the lobsters were tagged. This methods is known as Capture-mark-recapture (CMR). CMR is widely used to study of biota populations in wild nature. The aims of this study are to determine the recapture rate, growth rate, and movement of tagged scalloped spiny lobster in Prigi Bay. The tagged spiny lobster release was realesed at three locations, namely Damas, Karanggongso and Karangasem with 2,784 lobsters and was tagged with a red $T$ bar type that has a code. Observations of tagged scalloped spiny lobsters were carried out again throughout 2016 in Prigi Bay (February-December). The recapture rate of tagged spiny lobster is calculated using the proportion between the tagged lobster with the tagged lobster released. The tagged tagged spiny lobster growth rate is calculated again based on growth per unit time which is equal to the change in length divided by the change in age. Tagged spiny lobster movements are measured by distance from the location of release to the location of the tagged tagged spiny lobster is capture again. The recapture rate of tagged spiny lobster (P. homarus) marked in Gulf of Prigi as much as $4.7 \%$. The growth rate of tagged spiny lobster averaged $0.09 \pm 0.05 \mathrm{~mm} /$ day. The movement of tagged spiny lobster in Gulf of Prigi ranges from 0.1 to $11.36 \mathrm{~km}$. The movement of tagged spiny lobster has a random movement and remains in the coastal region.
\end{abstract}

Keywords: Scalloped spiny lobster; recapture rate; growth rate; movement; Gulf of Prigi 


\section{PENDAHULUAN}

Indonesia tercatat memiliki tujuh jenis lobster dari famili Palinuridae (spiny lobster) yaitu Panulirus homarus (lobster pasir), P. ornatus (lobster mutiara), $P$. longipes (lobster batik), P. versicolor (lobster bambu), P. polyphagus (lobster pakistan/lumpur), $P$. penicillatus (lobster batu) dan Puerulus mesodontus (Wijaya et al., 2017). Sub spesies dari $P$. longipes yaitu $P$. longipes femoristriga ditemukan di Perairan Lombok (Kalih, 2012), Sulawesi dan Seram (Wahyudin et al., 2016). Perairan ekosistem karang yang terbentang sepanjang Pantai Barat Sumatera, Selatan Jawa-Bali-Lombok hingga Papua merupakan wilayah sebaran spiny lobsterdi Indonesia (Chan, 1998).

Lobster merupakan sumber daya perikanan yang memiliki nilai ekonomis tinggi (Holthuis, 1991; Chan, 1998; Nurfiarini et al., 2016). Di Indonesia, lobster merupakan komoditas ekspor urutan ke empat dari kelompok udang-udangan (Junaedi et al., 2010) dengan nilai ekspor rata rata 4.267 ton/tahun atau sekitar US \$38,37 juta. Data DJPT (2015) menunjukkan bahwa produksi lobster Indonesia selama periode 2005-2014 fluktuatif cenderung meningkat dari 6.648 ton pada 2005 hingga mencapai 16.482 ton pada 2013, namun kemudian menurun sekitar empat ton pada 2014 dan terus menurun sampai saat ini.

Penurunan produksi tersebut diduga disebabkan oleh penangkapan berlebih pada berbagai ukuran mulai dari juvenil sampai dengan yang bertelur, perusakan habitat lobster karena penggunaan sianida dan adanya ghost fishing, serta kegagalan rekrutmen akibat perubahan iklim (Kartamihardja \& Satria, 2016). Selain hal tersebut, benih lobster (puerulus) semakin intensif dieksploitasi untuk tujuan ekspor. Upaya pengelolaan untuk menjaga populasi sumber daya lobster agar tetap lestari diantaranya dapat dilakukan dengan restoking lobster pada kawasan sentra lobster yang terindikasi mengalami penurunan stok.

Pada 2015 telah dilaksanakan percobaan penebaran lobster pasir (Panulirus homarus) di Perairan Teluk Prigi, Kabupaten Trenggalek. Perairan ini terpilih sebagai lokasi percobaan karena memiliki nilai kelayakan tertinggi bagi implementasi restoking lobster dibanding delapan wilayah sentra penghasil lobster lainnya (Nurfiarini et. al, 2016). Beberapa indikator utama yang menjadi bahan pertimbangan antara lain tren produksi lobster tahunan yang cenderung menurun dari 3,42 ton/tahun pada 2013 dan menjadi 2,6 ton pada 2014 (DKP Kab. Trenggalek, 2015), kondisi ekosistem karang masih tersedia cukup baik bagi kehidupan juvenil lobster serta kesiapan sistem sosial dalam pengelolaan perikanan lobster (Nurfiarini et al., 2016).

Pada percobaan tersebut, seluruh lobster pasir diberi tanda (tag). Metode ini dikenal sebagai metode Capture-mark-recapture (CMR). Metode CMR cukup banyak digunakan untuk mempelajari populasi biota di alam (Williams et al., 2002) diantaranya dapat memberikan informasi mengenai pertumbuhan, pergerakan di alam, tingkat kelangsungan hidup, tingkat kematian dan perkiraan stok suatu biota (Smith et al., 2001; King, 2007; González-Vicente et al., 2012). Pada penelitian ini, metode CMR dapat digunakan untuk mengetahui laju pertumbuhan lobster di alam dengan penandaan (tagging/marking) lobster secara individual dengan tanda yang dapat bertahan meskipun lobster mengalami moulting dan tidak mempengaruhi kelangsungan hidup, pertumbuhan atau perilaku lobster (Claverie \& Smith, 2007). Penelitian ini bertujuan untuk mengetahui tingkat tertangkap kembali, laju pertumbuhan, dan pergerakan lobster pasir bertanda yang tertangkap kembali di Teluk Prigi, Kabupaten Trenggalek sebagai informasi ilmiah yang dapat dimanfaatkan untuk membantu pengambilan kebijakan dalam pengelolaan perikanan lobster pasir secara khusus dan semua jenis lobster secara umum.

\section{BAHAN DAN METODE}

Penelitian dilaksanakan di Perairan Teluk Prigi, Kabupaten Trenggalek yang terletak di pesisir selatan Provinsi Jawa Timur (Gambar 1). Lobster pasir ( $P$. homarus) yang telah ditandai ditebar pada Desember 2015 di tiga lokasi yaitu Damas, Karanggongso dan Karangasem. Lobster pasir bertanda yang dirilis berjumlah 2.784 ekor (jantan 1.753 ekor dengan ratarata panjang karapas $46,0 \pm 4,8 \mathrm{~mm}$; betina 1.031 ekor dengan rata-rata panjang karapas $45,9 \pm 4,5 \mathrm{~mm}$ ).

Lobster pasir ditandai menggunakan tanda jenis T-bar berwarna merah (Gambar 2). Pemilihan jenis Tbar karena memiliki tingkat kelangsungan hidup yang baik pada lobster pasir yang telah ditandai (Wijaya et al., 2016). T-bar telah digunakan sebagai teknik standar untuk menandai beberapa jens biota (Ulmestrand \& Håkan, 2001; Dubula et al., 2005) dan memiliki masa pakai cukup lama (González-Vicente et al., 2012). 


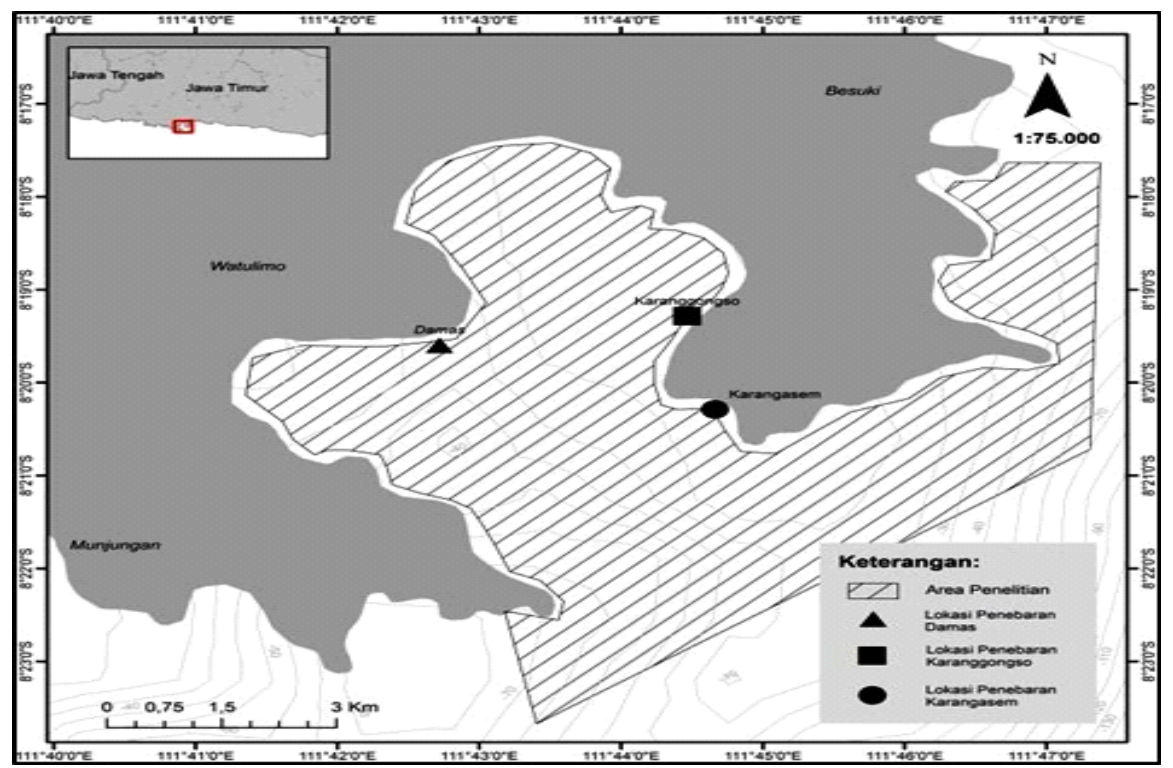

Gambar 1. Lokasi penelitian di Teluk Prigi. Figure 1. Research location in Gulf of Prigi .

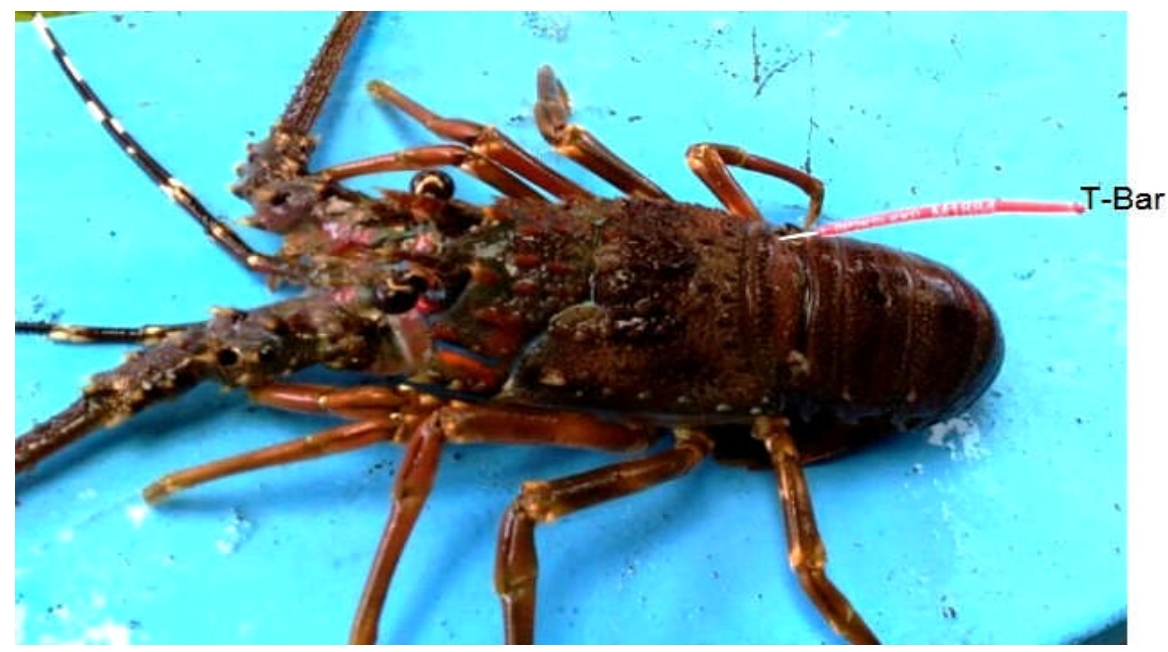

Gambar 2. Lobster pasir (P. homarus) yang ditandai dengan T-Bar berwarna merah.

Figure 2. Scalloped spiny lobster (P. homarus) tagged with red T-Bar.

Pengamatan tertangkap kembali lobster pasir bertanda dilakukan sepanjang tahun 2016 di Teluk Prigi (Februari-Desember). Pengamatan melibatkan beberapa pencatat data yang merupakan pengumpul lobster, petugas TPI, pelaku usaha di bidang lobster dan penyuluh perikanan setempat. Lobster yang tertangkap kembali dicatat nomor pada tanda T-bar, panjang karapas dan jenis kelaminnya. Lobster bertanda yang telah dicatat informasinya dilepaskan kembali ke alam dan nelayan penangkapnya diberi hadiah.

Tingkat tertangkap kembali lobster bertanda dihitung menggunakan proporsi persentase antara lobster bertanda yang tertangkap dengan lobster bertanda yang ditebar. Laju pertumbuhan lobster bertanda yang tertangkap kembali dihitung berdasarkan pertumbuhan per satuan waktu yang sama dengan perubahan panjang dibagi dengan perubahan umur (King, 2007):

$G R=\left(L_{2}-L_{1}\right) /\left(t_{2}-t_{1}\right)$

dimana:

$\mathrm{GR}=$ laju pertumbuhan ( $\mathrm{mm} / \mathrm{hari})$

$\mathrm{L}_{2}=$ panjang karapas lobster bertanda yang tertangkap kembali

$\mathrm{L}_{1}=$ panjang karapas awal lobster bertanda saat ditebar

$\mathrm{t}_{2}=$ waktu lobster bertanda tertangkap kembali

$\mathrm{t}_{1}=$ waktu lobster bertanda ditebar 
Pergerakan lobster bertanda diketahui dari laporan nelayan yang menangkap lobster bertanda tersebut. Jarak diukur dari lokasi tebar sampai dengan lokasi lobster pasir bertanda yang tertangkap kembali.

\section{HASIL DAN BAHASAN \\ Hasil}

\section{Tingkat Tertangkap Kembali}

Tingkat tertangkap kembali lobster pasir bertanda di Teluk Prigi sebesar 4,7\% (132 ekor dari jumlah yang ditebar 2.784 ekor). Dari 132 ekor lobster bertanda yang tertangkap kembali, hanya $68,2 \%$ yang dapat dianalisis lebih lanjut, selebihnya tidak dapat dilakukan analisis lebih lanjut disebabkan oleh beberapa hal antara lain lobster bertanda dilaporkan namun tidak dicatat dan kerusakan pada tanda (kode tidak terbaca) sehingga data awal tidak dapat diidentifikasi. Lobster pasir bertanda di Teluk Prigi yang tertangkap kembali cukup banyak di FebruariMei 2016 dan mulai menurun pada bulan-bulan setelahnya (Gambar 3).



Gambar 3. Lobster pasir bertanda yang tertangkap kembali di Teluk Prigi tahun 2016.

Figure 3. Recapture of tagged scalloped spiny lobster in Gulf of Prigi in 2016.

\section{Laju Pertumbuhan}

Lobster pasir bertanda pada kelompok ukuran panjang karapas saat tebar 35-38 mm memiliki laju pertumbuhan tertinggi sebesar $0,18 \pm 0,06 \mathrm{~mm} /$ hari (jantan) dan 0,23 mm/hari (betina). Pada kelompok ukuran terkecil tersebut nampak laju pertumbuhan lobster pasir bertanda memiliki laju pertumbuhan terbesar dibanding kelompok ukuran yang lebih besar. Lobster pasir bertanda jantan memiliki laju pertumbuhan cukup bervariasi diantara beberapa kelompok ukuran. Pertumbuhan lobster pasir bertanda jantan pada kelompok ukuran panjang karapas 47-50 $\mathrm{mm}$ memiliki laju pertumbuhan terkecil dibanding kelompok ukuran lainnya yaitu sebesar 0,05 $\pm 0,04$ $\mathrm{mm} /$ hari.

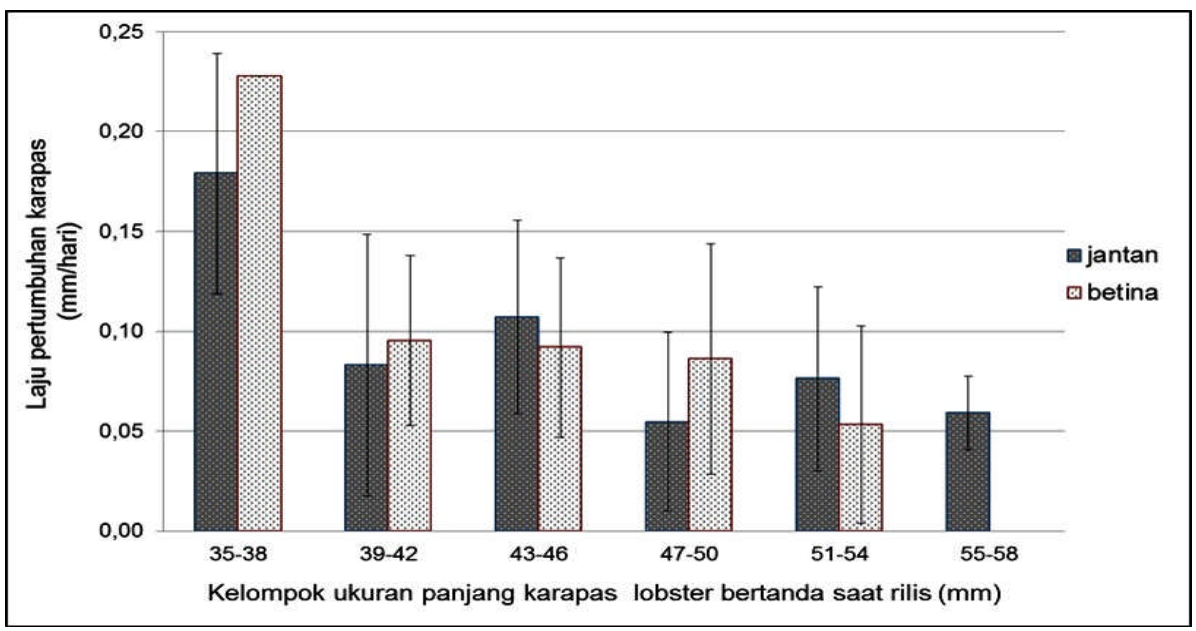

Gambar 4. Laju pertumbuhan lobster pasir bertanda di Teluk Prigi.

Figure 4. Growth rate of tagged scalloped spiny lobster in Gulf of Prigi. 
Pertumbuhan lobster pasir bertanda betina pada kelompok ukuran panjang karapas 51-54 mm memiliki laju pertumbuhan terkecil dibanding kelompok ukuran lainnya yaitu sebesar $0,05 \pm 0,05 \mathrm{~mm} / \mathrm{hari}$. Pada lobster pasir bertanda betina memiliki laju pertumbuhan yang memiliki kecenderungan menurun pada kelompok ukuran yang lebih besar. Secara umum, lobster pasir bertanda yang tertangkap kembali pada kelompok ukuran panjang karapas yang lebih kecil memiliki kecenderungan laju pertumbuhan cukup tinggi dibandingkan dengan kelompok ukuran panjang karapas yang lebih besar.

\section{Pergerakan}

Pergerakan lobster pasir bertanda yang tertangkap kembali di Teluk Prigi memiliki arah pergerakan ke arah barat mencapai daerah Klopo dan paling timur mencapai daerah Njuwor. Pergerakan lobster nampak cukup banyak menyebar di area dalam Teluk Prigi. Pergerakan lobster pasir bertanda yang tertangkap kembali di Teluk Prigi berkisar antara 0,1-11,36 km. (Gambar 5).

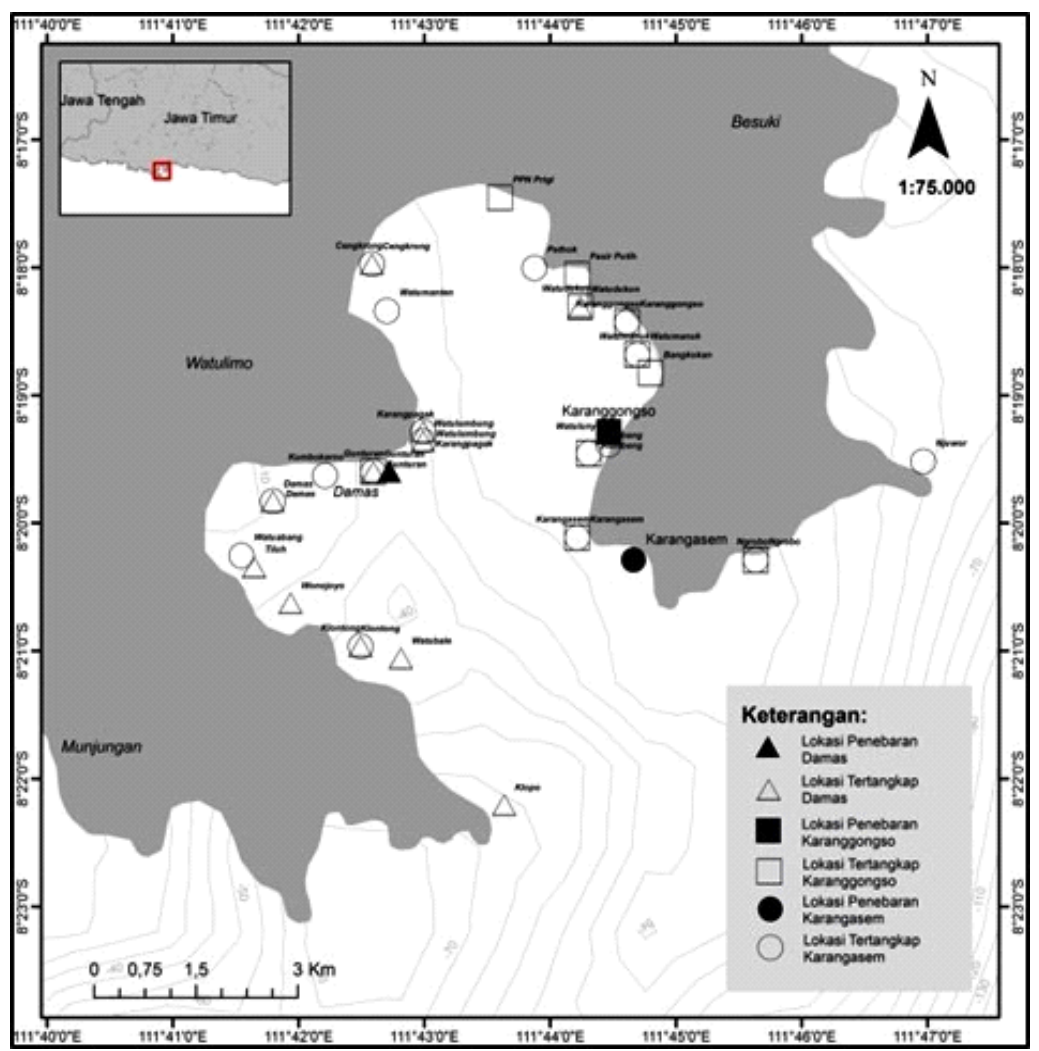

Gambar 5. Pergerakan lobster pasir bertanda di Teluk Prigi.

Figure 5. Movement of tagged scalloped spiny lobster in Gulf of Prigi.

\section{Bahasan \\ Tingkat Tertangkap Kembali}

Tingkat tertangkap kembali lobster pasir bertanda di Teluk Prigi sebesar 4,7\% (132 ekor dari jumlah yang ditebar 2.784 ekor) (Gambar 3). Lobster pasir bertanda di Teluk Prigi yang tertangkap kembali cukup banyak di Februari-Mei 2016 dan mulai menurun pada bulan-bulan setelahnya. Tingkat tertangkap kembali lobster pasir bertanda di Teluk Prigi yang cukup kecil tersebut disebabkan oleh beberapa faktor. Di Teluk Prigi, pada bulan Januari belum ada lobster pasir bertanda yang tercatat tertangkap kembali disebabkan pada bulan januari belum dilakukan pencatatan. Hal tersebut disebabkan penelitian di Teluk Prigi baru dapat dilakukan mulai bulan Februari. Pada bulan Februari-April masih tergolong musim puncak lobster sehingga memungkinkan hasil tangkap kembali lobster pasir bertanda cukup baik. Pada bulan berikutnya sampai dengan Agustus lobster pasir yang tertangkap kembali mengalami penurunan dikarenakan bulan tersebut masih tergolong musim paceklik. Selain hal tersebut, nelayan lobster tidak banyak yang beroperasi menangkap lobster disebabkan oleh kondisi perairan laut yang tidak memungkinkan seperti cuaca yang tidak menentu berupa gelombang besar.

Tingkat tertangkap kembali lobster pasir bertanda Teluk Prigi $(4,7 \%)$ pada penelitian ini cukup rendah jika melihat tingkat ketertangkapan kembali lobster pasir (P. homarus) bertanda di India sebesar 27,6\% (Mohamed \& George, 1968). Penelitian lain menggunakan lobster bambu ( $P$. versicolor) di Australia menunjukkan tingkat tertangkap kembali 
sebesar 55 \% (Frisch, 2007). Penelitian menggunakan lobster jenis $P$. argus juga dilakukan oleh Ley-Cooper et al., 2012 dengan tingkat tertangkap kembali $34 \%$ dan Ehrhardt (2008) dengan tingkat tertangkap kembali sebesar $19.91 \%$ (jantan) dan $16.89 \%$ (betina). Tingkat tertangkap kembali juga diduga dipengaruhi faktor pemangsaan oleh predator dimana lobster ukuran panjang karapas 20-40 mm merupakan komposisi makanan yang ditemukan pada beberapa jenis ikan yang lebih besar (Butler IV \& Herrnkind, 2000).

\section{Laju Pertumbuhan}

Laju pertumbuhan seluruh sampel lobster pasir bertanda yang tertangkap kembali di Teluk Prigi berkisar 0,0-0,24 mm/hari dengan rata-rata 0,09 $\pm 0,05$ $\mathrm{mm} /$ hari. Laju pertumbuhan lobster pasir bertanda pada Teluk Prigi berada pada kisaran laju pertumbuhan lobster pasir bertanda yang dilakukan di India yang berkisar 0,04-0,35 mm/hari (Mohamed \& George (1968). Lobster bertanda di alam pada penelitian di Teluk Prigi memiliki laju pertumbuhan lebih baik daripada laju pertumbuhan lobster pasir pada kolam penampungan yang berkisar 0,05-0,10 mm/hari (Berry, $1971^{\mathrm{a}}$ ) dan 0,01-0,06 mm/hari (Vijayakumaran et al., 2010).

Laju pertumbuhan lobster pasir bertanda di Teluk Prigi pada kelompok ukuran panjang karapas paling kecil (35-38 mm) menunjukkan laju pertumbuhan tertinggi baik pada lobster jantan $(0,18 \pm 0,06 \mathrm{~mm} /$ hari) maupun betina $(0,23 \mathrm{~mm} /$ hari) dibandingkan dengan kelompok ukuran lainnya. Laju pertumbuhan lobster pasir bertanda memiliki kecenderungan menurun pada kelas ukuran panjang karapas yang lebih besar (Gambar 4). Mohamed \& George (1968) dan Nair et al. (1981) menyebutkan bahwa lobster pasir di alam menunjukkan laju pertumbuhan cukup cepat pada awal kehidupan mereka dan setelah itu proses pertumbuhan akan melambat. Laju pertumbuhan lobster pasir pada kolam penampungan juga menunjukkan pada kelompok ukuran panjang karapas yang masih kecil memiliki laju pertumbuhan lebih tinggi daripada kelompok ukuran panjang karapas yang lebih besar (Kulmiye \& Mavuti, 2005). Biota yang masih muda umumnya memiliki pertumbuhan yang cepat karena makanan digunakan untuk menambah panjang berat tubuhnya dan pergerakannya masih terbatas. Sedangkan pada biota yang mulai dewasa, pertumbuhan tetap berjalan namun mulai melambat (Effendie, 1997).

Lobster pasir bertanda jantan di Teluk Prigi menunjukkan memiliki laju pertumbuhan lebih tinggi dibandingkan lobster bertanda betina pada kelompok ukuran panjang karapas 43-46 mm dan 51-54 mm. Lobster pasir bertanda jantan menunjukkan laju pertumbuhan paling tinggi pada kelompok ukuran paling kecil (35-38 $\mathrm{mm}$ ) dan cukup beragam pada setiap kelas ukuran di atasnya. Lobster betina memiliki laju pertumbuhan lebih tinggi daripada lobster bertanda jantan pada kelompok ukuran panjang karapas 35-38 mm, 39-42 mm, dan 47-50 mm. Lobster pasir bertanda betina menunjukkan laju pertumbuhan paling tinggi pada kelompok ukuran paling kecil (35-38 mm) dan memiliki kecenderungan menurun pada kelompok ukuran panjang karapas yang lebih besar. Mohamed \& George (1968) mendapatkan hasil lobster pasir jantan memiliki laju pertumbuhan panjang karapas lebih cepat daripada lobster betina pada percobaan penandaan lobster pasir di India. Laju pertumbuhan lobster pasir pada kolam pemeliharaan menunjukkan hasil lobster jantan memiliki laju pertumbuhan lebih tinggi dari lobster betina (Jong, 1993; Thomas, 1972). Secara umum pertumbuhan lobster betina lebih lambat dibandingkan lobster jantan disebabkan adanya proses pematangan ovarium (Aiken, 1980; Hartnoll, 1985).

Smale (1978) dan Kulmiye \& Mavuti (2005) mendapati hasil bahwa pertumbuhan lobster betina lebih cepat dibandingkan lobster jantan. Namun, Berry $\left(1971^{\text {b }}\right.$ ) mendapatkan hasil lobster jantan dan betina memiliki laju pertumbuhan yang sama pada masa juvenil. Pertumbuhan lobster dipengaruhi oleh jenis habitat dan ketersedian tempat perlindungan (Crear et al., 2000; James et al., 2001). Lobster jantan tumbuh lebih cepat daripada lobster betina disebabkan kompetisi dalam memanfaatkan makanan jika makanan yang tersedia di alam sedikit, namun tidak ada perbedaan pertumbuhan antara lobster jantan dan betina jika ketersediaan makanan cukup (Chittleborough, 1976).

Laju pertumbuhan lobster pasir bertanda dipengaruhi juga ketersediaan makanan alami yang sesuai untuk lobster di alam. Joll \& Phillips (1984) menemukan bahwa lobster memiliki laju pertumbuhan berbeda pada habitat karang tergantung pada ketersediaan makanan. Pada perairan pantai berkarang umumnya menyediakan sumber makanan dan berlindung untuk lobster muda (Acosta \& Butler IV, 1997). Ketersediaan makanan alami di Teluk Prigi berupa moluska dan krustasea cukup tersedia dapat diketahui dari komposisi makanan lobster pasir di Teluk Prigi yang dominan berisi moluska dan sebagian lainnya berupa detritus dan krustasea (Wijaya et al., 2017). McGarvey et al. (1999) menyebutkan bahwa isi lambung lobster yang memiliki populasi laju pertumbuhan tinggi didominasi moluska, beragam organisme dan alga, sedangkan isi lambung lobster 
yang memiliki populasi laju pertumbuhan rendah didominasi oleh alga koralin dan kurang beragam. Kompetisi antar jenis lobster dalam memanfaatkan makanan alami diduga dapat mempengaruhi laju pertumbuhan lobster. Wijaya et al. (2017) menemukan kompetisi yang tinggi antara lobster pasir ( $P$. homarus) dengan lobster mutiara $(P$. ornatus) di Teluk Prigi dimana keduanya memanfaatkan moluska sebagai makanan utama.

\section{Pergerakan}

Pergerakan lobster pasir bertanda yang tertangkap kembali di Teluk Prigi berkisar antara 0,1-11,36 km. Pergerakan lobster pasir bertanda yang tertangkap kembali di Teluk Prigi ke arah barat mencapai daerah Klopo dan paling timur mencapai daerah Njuwor. Di India, Mohamed \& George (1968) mendapatkan semua lobster pasir bertanda tertangkap kembali pada kisaran jarak 0,25-7 km dan hanya satu ekor lobster bertanda yang tertangkap kembali pada jarak 12 km dari lokasi tebar.

Lobster pasir bertanda di Teluk Prigi ditebar di tiga lokasi yaitu Teluk Damas, Karanggongso dan Karangasem. Pergerakan lobster pasir bertanda yang berasal dari masing-masing lokasi tebar dapat dilihat pada Gambar 5. Lobster pasir bertanda yang ditebar di Teluk Damas melakukan pergerakan berkisar antara 0,1-11,4 km. Pergerakan lobster mayoritas di sekitar Teluk Damas (Teluk Prigi bagian barat) menuju ke selatan sampai dengan mulut Teluk Prigi (wilayah Klopo). Sebagian kecil lainnya bergerak ke utara (Cengkrong) dan timur (Karanggongso). Lobster pasir bertanda yang ditebar di Karanggongso memiliki pergerakan berkisar antara 0,4-5,6 km. Pergerakan lobster mayoritas di sekitar Karanggongso (Teluk Prigi bagian timur) menuju ke utara sampai dengan Pelabuhan Perikanan Nusantara Prigi. Sebagian kecil lainnya bergerak ke arah selatan sampai dengan keluar mulut Teluk Prigi di wilayah Ngrobo. Lobster pasir bertanda yang ditebar di Karangasem memiliki pergerakan berkisar antara 0,73-11,2 km. Pergerakan lobster yang ditebar di Karangasem memiliki kecenderungan masuk ke dalam Teluk Prigi dan menyebar di bagian barat dan timur. Sebagian kecil lainnya bergerak ke arah timur sampai wilayah Njuwor.

Seluruh lobster bertanda di Teluk Prigi yang tertangkap kembali memiliki arah pergerakan yang acak namun masih berada pada wilayah pantai. Pergerakan lobster pasir bertanda di Teluk Prigi memiliki kemiripan dengan pergerakan lobster pasir bertanda di India yang memiliki pergerakan acak dan menuju pantai dimana lobster berusaha kembali ke habitat alami berupa dasar laut berbatu yang dekat dengan pantai serta pengaruh pasang surut air laut (Mohamed \& George, 1968). Lobster pasir memiliki habitat alami di perairan dangkal dengan kedalaman 1-5 m diantara terumbu karang, bebatuan, pecahan karang namun kadang ditemukan di perairan yang cukup keruh dan kedalaman hingga $90 \mathrm{~m}$ (Holthuis, 1991; Chan, 1998; Milton et al., 2012). Pada perairan pantai berkarang umumnya menyediakan sumber makanan dan berlindung untuk lobster muda (Acosta \& Butler IV, 1997).

Beberapa hal yang dapat mempengaruhi pergerakan lobster adalah untuk mendapatkan peluang makan (Phillips, 1983), peningkatan pertumbuhan (Campbell, 1986), mencari lokasi terbaik untuk berkembang biak (Moore \& MacFarlane, 1984; Booth, 1997) dan menghindari habitat yang tidak optimal seperti gangguan fisik yang tinggi (Herrnkind, 1985), salinitas rendah (Jury et al., 1994) dan oksigen rendah (Cockcroft, 2001). Dalam hal pergerakan lobster yang dipengaruhi untuk mendapatkan peluang makan (Phillips, 1983), lobster pasir di Teluk Prigi yang memiliki kebiasaan makanan dominan berupa moluska (Wijaya et al., 2017) diduga memiliki pergerakan mencari lokasi yang memiliki ketersediaan makanan alami berupa moluska. Karnofsky et al. (1989) menyebutkan bahwa lobster di perairan berupa teluk sekitar $52 \%$ dari populasi lobster menetap dan $48 \%$ yang bersifat sementara. Childress \& Jury (2006) menjelaskan bahwa lobster pada tempat dan waktu tertentu dapat dibagi menjadi kategori menetap atau sementara.

\section{KESIMPULAN}

Tingkat tertangkap kembali lobster pasir ( $P$. homarus) bertanda di Teluk Prigi sebanyak 4,7 \%. Laju pertumbuhan lobster pasir yang tertangkap kembali rata-rata 0,09 $\pm 0,05 \mathrm{~mm} /$ hari. Pergerakan lobster pasir bertanda yang tertangkap kembali di Teluk Prigi berkisar antara 0,1-11,36 km memiliki arah ke barat mencapai wilayah Klopo dan timur mencapai wilayah Njuwor. Pergerakan lobster pasir bertanda memiliki kecenderungan acak namun tetap pada wilayah pantai. Pada penelitian penandaan lobster yang akan datang sebaiknya dilakukan pengamatan pada perairan di Kabupaten yang bersebelahan dengan lokasi tebar lobster bertanda. Selain itu juga dapat disarankan menjaga habitat asuhan lobster dengan batasan daya jelajah lobster bertanda.

\section{PERSANTUNAN}

Tulisan ini merupakan kontribusi dari kegiatan Balai Penelitian Pemulihan dan Konservasi Sumber Daya lkan (BP2KSI) tahun anggaran 2016 dengan judul 
kegiatan Kajian Hasil Restocking Lobster dan Penempatan Terumbu Karang Buatan (TKB) di Kawasan Konservasi Indonesia.

\section{DAFTAR PUSTAKA}

Acosta, C. A., \& Butler IV, M. J. (1997). Role of mangrove habitat as a nursery for juvenile spiny lobster, Panulirus argus, in Belize. Marine \& Freshwater Research, 48, 721-727. https://doi.org/ 10.1071/MF96105.

Aiken, D. E. (1980). Molting and growth. In: J. S. Cobb \& B. F. Phillips, The Biology and Management of Lobsters, 2, 91-163. (Academic Press, New York).

Berry, P. F. (1971) ${ }^{a}$. The spiny lobsters (Palinuridae) of the east coast of southern Africa: distribution and ecological notes. Investigation Reports Oceanographic Research Institute, 27, 1-23.

Berry, P. F. (1971) b. The biology of the spiny lobster Panulirus homarus (Linnaeus) of the east coast of southern Africa. South African Oceanogr. Res. Inst. Invest. Rep., 28, 1-75.

Booth, J. D. (1997) Long-distance movements in Jasus spp. and their role in larval recruitment. Bulletin of Marine Science, 61, 111-28.

Butler IV, M. J. \& Herrnkind, W. F. (2000). Puerulus and juvenile ecology. In Phillips, B. F. \& Kittaka, J. (Eds.), Spiny lobster: Fisheries and culture. Second Edition (pp. 276-301). Oxford : Fishing New Books.

Campbell, A., \& Stasko, A. B. (1986) Movements of lobsters tagged in the Bay of Fundy, Canada. Marine Biology, 92, 393-404.

Chan, T. Y. (1998). Lobsters. In Carpenter, K. E. \& Niem, V. H. (Eds.), FAO species identification guide for fisherh purposes. The living marine resources of Western Central Pacific. Volume 2. Chepalopods, crustaceans, holothurians and sharks (pp. 973-981). Rome : FAO.

Childress, M. J. \& Jury, S. H. (2006). Behaviour. In Phillips, B. F. (Ed.), Lobsters : biology, management, aquaculture, and fisheries (pp. 78-112). Oxford, UK : Blackwell Publishing Ltd.

Chittleborough, R. G. (1976). Growth of juvenile Panulirus longipes cygnus George on coastal reefs compared with those reared under optimal envi- ronmental conditions. Australian Journ. Mar. Freshwater Res., 27, 279-295.

Claverie, T. \& Smith, I. P. (2007). A comparison of the effect of three common tagging methods on the survival of the galatheid Munida rugosa (Fabricius, 1775). Fish. Res, 86, 285-288.

Cockcroft, A.C. (2001) Jasus lalandii walkouts or mass strandings in South Africa during the 1990s: an overview. Marine and Freshwater Research, 52, 1085-94.

Crear, B. J., Thomas, C. W., Hart, P. R., \& Carter, C. G. (2000). Growth of juvenile southern rock lobster Jasus edwardsii is influenced by diet and temperature, whilst survival is influenced by diet and tank environment. Aquaculture, 190, 169-182.

DKP Kab. Trenggalek. (2015). Profil potensi perikanan kabupaten Trenggalek. Laporan Tahunan (Tidak dipubikasikan).

DJPT. (2015). Statistik perikanan tangkap berdasarkan Wilayah Pengelolaan Perikanan Negara Republik Indonesia (WPP NRI) 2005-2014. Jakarta : Direktorat Jenderal Perikanan Tangkap. $966 \mathrm{hlm}$.

Dubula, O., Groeneveld, J. C., Santos, J., van Zyl, D. L., Brouwer, S. L., van den Heever, N., \& McCue, S. A. (2005). Effects of tag-related injuries and timing of tagging on growth of rock lobster, Jasus lalandii. Fish. Res. (74), 1-10.

Effendie, M. I. (1997). Biologi perikanan (p. 163). Yogyakarta : Yayasan Pustaka Nusatama.

Ehrhardt, N. M. (2008). Estimating growth of the Florida spiny lobster, Panulirus argus, from molt frequency and size increment data derived from tag and recapture experiments. Fisheries Research, (93), 332-337. DOI:10.1016/ j.fishres.2008.06.008.

Frisch, A. J. (2007). Short- and long-term movements of painted lobster (Panulirus versicolor) on a coral reef at Northwest Island, Australia. Coral Reefs, (26), 311-317. DOI 10.1007/s00338-006-0194-6.

González-Vicente L., Díaz, D., Mallol, S. \& Goñi, R. (2012). Tag loss in the lobster Palinurus elephas (Fabricius, 1787) and implications for population assessment with capture-mark-recapture methods. Fish. Res., (129-130), 1-7. 
Hartnoll, R. G. (1985). Growth, sexual maturity and reproductive output. In: A. Wenner, Crustacean issues, 3, 101-128. (Balkema Press, Rotterdam).

Herrnkind, W. F. (1985). Evolution and mechanisms of mass single-file migration in spiny lobster: synopsis. Contributions in Marine Science, 27, 197211.

Holthuis, L. B. (1991). FAO species catalogue. Vol. 13. Marine lobsters of the world. An annotated and illustrated catalogue of species of interest to fisheries known to date. FAO Fisheries Synopsis. No. 125, Vol. 13. Rome : FAO. 292 p.

James, P. J., Tong, L. J., \& Paewai, M. P. (2001). Effect of stocking density and shelter on growth and mortality of early juvenile Jasus edwardsii held in captivity. Mar. Freshwat. Res., 52, 1413-1417.

Joll, L. M., \& Phillips, B. F. (1984). Natural diet and growth of juvenile western rock lobsters Panulirus cygnus George. Journal of Experimental Marine Biology and Ecology, 75(2), 145-69.

Jong, K. (1993) Growth of the Spiny Lobster Panulirus homarus (Linnaeus, 1758), Depending on Sex and Influenced by Reproduction (Decapoda, Palinuridae). Crustaceana, 64(1), 18-23.

Junaedi, N., Cokrowati. \& Abidin, Z. (2010). Aspek produksi lobster (Panulirus sp.) di Perairan Teluk Ekas Pulau Lombok. Jurnal Kelautan 3(1), 29.

Jury, S. H., Kinnison, M., Howell, W. H., \& Watson, W. (1994). The behavior of lobsters in response to reduced salinity. Journal of Experimental Marine Biology and Ecology, 180, 23-37.

Kalih, L. A. T. T. W. S. (2012). Keragaman serta distribusi lobster anggota palinuridae dan scyllaridae di perairan pantai pulau Lombok. Tesis. Yogyakarta : Program Pasca Sarjana Universitas Gadjah Mada.

Karnofsky, E. B., Atema, J., \& Elgin, R. H. (1989). Field observations of social behavior, shelter use, and foraging in the lobster, Homarus americanus. Biological Bulletin, 176, 239-246.

King, M. (2007). Fisheries biology, Assessment and Management, Second edition (p. 382). Oxford, UK: Blackwell Publishing Ltd.

Kulmiye, A. J. \& Mavuti, K. M. (2005). Growth and moulting of captive Panulirus homarus homarus in Kenya, western Indian Ocean. New Zealand Journal of Marine and Freshwater Research, 39(3), 539-549. DOI: 10.1080/00288330.2005.9517332.

Ley-Cooper, K., de Lestang, S., Phillips, B. F. \& Lozano-Alvarez, E. (2012). Estimates of exploitation rates of the spiny lobster fishery for Panulirus argus from tagging within the Bahía Espíritu Santo "Sian Ka'an" Biosphere Reserve, Mexican Caribbean. Marine Biology Research. 9(1), 88-96. DOI: 10.1080/17451000.2012.727434.

McGarvey, R., Ferguson, G. J. \& Prescott, J. H. (1999). Spatial variation in mean growth rates at size of southern rock lobster, Jasus edwardsii, in South Australian waters. Marine and Freshwater Research, 50(4), 333-42.

Milton, D. A., Proctor, C., Satria, F., \& West, R.J. (Eds.) (2012). South coast Java Lobster fishery. Report prepared for ACIAR Project FIS/2006/142, Developing new assessment and policy frameworks for Indonesia's marine fisheries, including the control and management of Illegal, Unregulated and Unreported (IUU) Fishing. Australian National Centre for Ocean Resources and Security (ANCORS). Australia : University of Wollongong. $46 \mathrm{p}$.

Mohamed, K. H. \& George, M. J. (1968). Results of the tagging experiments on the Indian Spiny lobster, Panulirus homarus (Linnaeus) - Movement and growth. Indian Journal of Fisheries, 15(1\&2), 15-26.

Moore, R. \& MacFarlane, J. W. (1984) Migrations of the ornate rock lobster, Panulirus ornatus (Fabricius), in Papua New Guinea. Australian Journal of Marine and Freshwater Research, 35, 187-212.

Nair, R.V., Soundararajan, R., \& Nandakumar, G. (1981). Observations on growth and moulting of spiny lobsters Panulirus homarus (Linnaeus), $P$. ornatus (Fabricius) and P. penicillatus (Olivier) in captivity. Indian Journal of Fisheries, 28(1\&2), 25-35.

Nurfiarini, A., Wijaya, D., Mujiyanto, Satria, F., \& Kartamihardja, E.S. (2016). Pendekatan sosialekologi untuk penilaian kesesuaian lokasi $R e$ stocking lobster pasir Panulirus homarus (Linnaeus, 1758) pada beberapa perairan di Indonesia. J. Lit. Perik. Ind., 22(2), 123-138.

Phillips, B. F. (1983). Migrations of pre-adult western rock lobsters, Panulirus cygnus, in Western Australia. Marine Biology, 76, 311-18. 
Smale, M. J. (1978). Migration, growth and feeding in the Natal rock lobster Panulirus homarus (Linnaeus). South African Oceanogr. Res. Inst. Invest. Rep, 47, 1-56.

Smith, I. P., Jensen, A. C., Collins, K. J., \& Mattey, E. L. (2001). Movement of wild European lobsters, Homarus gammarus (L.), in natural habitat. Mar. Ecol. Prog. Ser, 222, 177-186.

Thomas, M. M. (1972). Growth of the spiny lobster, Panulirus homarus (Linnaeus), in captivity. Indian Journal of Fisheries, 19 (1\&2), 125-129.

Ulmestrand, M. \& Håkan, E. (2001). Growth of Norway lobster, Nephrops norvegicus (Linnaeus 1758), in the Skagerrak, estimated from tagging experiments and length frequency data. ICES J. Mar. Sci, (58), 1133-1326.

Vijayakumaran, M., Anbarasu, M., \& Kumar, T. S. (2010). Moulting and growth in communal and individual rearing of the spiny lobster, Panulirus homarus. Journal of the Marine Biological Association of India, 52(2), 274-281.
Wahyudin R. A., Hakim A. A., Boer M., Fajaralllah A., \& Wardiatno, Y. (2016). New records of Panulirus femoristriga Von Morten, 1872 (Crustacea Achelata Palinuridae) from Celebes and Seram Island, Indonesia. Biodiversity Journal, 7(4), 901906.

Wijaya, D., Satria, F., \& Kartamiharja, E. S. (2016). Efektivitas penggunaan berbagai jenis tag untuk mengetahui kelangsungan hidup lobster pasir (Panulirus homarus Linnaeus, 1758). J. Lit. Perik. Ind. 22(3), 189-196. DOI: 10.15578/ jppi.22.3.2016.189-196.

Wijaya, D., Nurfiarini, A., Nastiti, A. S., \& Riswanto. (2017). Kebiasaan makanan, luas dan tumpang tindih relung beberapa jenis lobster di Teluk Prigi, Kabupaten Trenggalek. BAWAL, 9(3), 153161. DOI: 10.15578/bawal.9.3.2017.153-161.

Williams, B. K., Nichols, J. D., \& Conroy, M. J. (2002). Analysis and management of animal populations. modeling, estimation, and decision making. San Diego : Academic Press. 